\title{
Evaluation of the effect of carnosine, its novel derivative trolox-carnosine and trolox in a pre-clinical study focussing on the regulation of immunity Hodnotenie účinku karnozínu, jeho derivátu karnozín-troloxu a troloxu v predklinickej štúdii zameranej na reguláciu imunity
}

Received 24 June 2016, accepted 20 July 2016

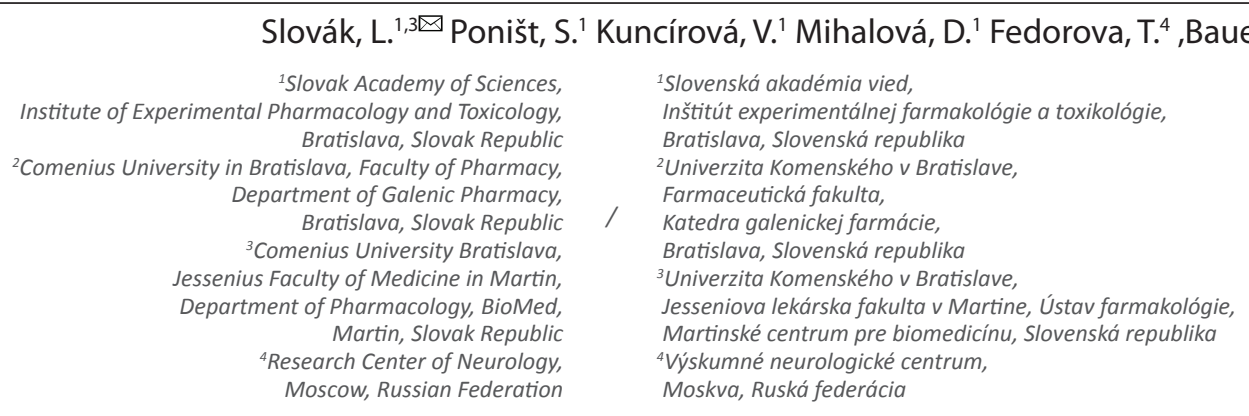

Abstract Trolox-carnosine (CARN-T) was synthesised due to its resistance against degradation by carnosinase and in order to improve its antioxidant capacity. The aim of this study was to evaluate the effect of trolox (TRO), carnosine (CARN), and its derivative with trolox in rat adjuvant arthritis (AA). CARN and CARN-T did not cause any weight reduction, which is a great advantage in inflammatory arthritis. Moreover, all the antioxidants administered had comparable beneficial therapeutic effects on hind paw swelling, an important marker of inflammation.

Slovak Trolox-karnozín (CARN-T) bol pripravený so zámerom zabránit’ jeho degradácií enzýmom karnozinázou a zlepšit antioxidačnú abstract kapacitu karnozínu. Cielom tejto štúdie bolo zhodnotit účinok troloxu (TRO), karnozínu (CARN) a jeho derivátu s troloxom v adjuvantnej artritíde. CARN a CARN-T nespôsobovali žiaden úbytok hmotnosti, čo predstavuje výhodu v zápalovej artritíde. Okrem toho, všetky podávané antioxidanty mali porovnatel'ný terapeutický účinok na opuch zadných končatín, ktorý predstavuje dôležitý parameter zápalu.

Keywords Trolox-carnosine-Adjuvant arthritis-Inflammation

Klúčové Trolox-karnozín- Adjuvantná artritída-Zápal

slová:

\section{INTRODUCTION}

Carnosine (CARN) is a dipeptide consisting of $\beta$-alanine and L-histidine [1]. CARN-T was synthesised due to its resistance against degradation by carnosinase and in order to improve its antioxidant capacity. TRO - a water-soluble analogue of vitamin E-is used in biological applications to reduce oxidative stress, and it was selected for addition with CARN. CARN-T improved the long-term memory, and unlike CARN, it was reported to increase the life-span of both male and female fruit flies [2]. At the same time, CARN-T is more stable against a human serum carnosinase attack and circulates longer in the blood stream [3].The aim of this study was to evaluate the therapeutic potential of all above-mentioned antioxidants in rat adjuvant arthritis (AA) and their impact on inflammation processes in plasma.

\section{MATERIAL AND METHODS}

\section{Animal protocol}

Adult male Lewis rats weighing 160-180 g were obtained from the Breeding Farm Dobrá Voda (Slovakia). The rats had free access to standard pellet diet and tap water. The experimental

*E-mail: lukas.slovak@savba.sk

๑ Acta Facultatis Pharmaceuticae Universitatis Comenianae 
protocol was approved by the Ethics Committee of the Institute of Experimental Pharmacology and Toxicology and by the Slovak State Veterinary and Food Administration in accordance with the European Convention for the Protection of Vertebrate AnimalsUsedforExperimentalandOtherScientificPurposesand with Slovak legislation. AA was induced by a single intradermal injection of heat-inactivated Mycobacterium butyricum in incomplete Freund's adjuvant (Difco Laboratories, Detroit, MI, USA) near the tail base [4]. The rats were randomised into five groups: $\mathrm{CO}$ - healthy animals not treated, AA - untreated adjuvant-induced arthritis group, arthritic groups treated by: CARN $150 \mathrm{mg} / \mathrm{kg}$ b.w., TRO $41 \mathrm{mg} / \mathrm{kg}$ b.w. and CARN-T 75mg/ $\mathrm{kg}$ b.w. in daily oral doses over 28 days. On day 14 of the experiment, blood samples were withdrawn from the retroorbital plexus under Zoletil $/$ xylasine anaesthesia. The animals were sacrificed on day 28 of the experiment. All samples were stored at $-70^{\circ} \mathrm{C}$ until biochemical analysis.

\section{Clinical parameters: increase in the hind paw volume and change of body weight}

The hind paw volume (HPV, \%) increase was calculated as the percentage increase in the HPV on a given experimental day relative to the HPV at the beginning of the experiment. The hind paw volume was recorded on days 1, 14, 21, and 28 with the use of an electronic water plethysmometer (UGO BASILE, Comerio-Varese, Italy). The change in body weight (CBW; g) was measured on days 1, 14, 21, and 28. CBW was calculated as the difference of the body mass measured on days 14, 21, and 28 and the body weight measured at the beginning of the experiment (day 1 ).

\section{Measurement of monocyte chemotactic protein-1 (MCP-1), interleukin $1 \beta$ (IL-1 $\beta)$, and matrix metalloproteinase 9 (MMP-9) in plasma}

For determination of plasmatic concentration of monocyte chemotactic protein-1 (MCP-1), ELISA kits from eBioscience and of interleukin $1 \beta$ (IL-1 $\beta$ ) and matrix metalloproteinase 9 (MMP-9), ELISA kits from R\&D Systems Quantikine were used. Assay procedures were applied as described in the product manual.

\section{Statistical analyses}

The mean and S.E.M. values were calculated for each parameter in each group (8 animals per experimental group). Statistically significant differences among the treated groups, untreated group, and control groups were tested using parametric Analysis of Variance (ANOVA). Post hoc test (Tukey-Kramer) was applied in situations where differences among the groups were significant at the level of significance $\alpha=0.05$. After post hoc testing, the following significance designations were specified: extremely significant $(p<0.001)$, highly significant $(p<0.01)$, significant $(p<0.05)$, not significant $(p>0.05)$.

\section{RESULTS}

\section{Clinical parameters}

The body weight of arthritic animals decreased during the experiment. The most noticeable weight reduction was on day 21, as compared to healthy animals. Neither of the substances administered did affect the change of body weight on experimental days 14 and 21 , but on day 28, TRO $(p<0.01)$ aggravated the weight reduction caused by AA. On day 14, CARN-T $(p<0.05)$ and TRO $(p<0.01)$ reduced the hind paw volume of the animals. On day 21 , only TRO $(p<0.05)$ had this effect, and on day 28, all substances administered (CARN $p<$ 0.01 , CARN-T $p<0.001$, and TRO $p<0.001$ ) were effective in decreasing the hind paw volume (Tab. 1).

\section{Markers of inflammation in plasma on day 14}

During $A A$, the plasmatic level of IL-1 $\beta$ was increased more than 11 times on day 14. Each of the substances administered decreased significantly the levels of IL-1 $\beta$ ( $p<0.001)$. CARN-T $(p<0.05)$ and TRO $(p<0.01)$ reduced the levels of MCP-1 in plasma. Moreover, CARN, CARN-T, and TRO were effective in reducing the MMP-9 levels ( $p<0.001)$ (Tab. 2).

\section{DISCUSSION AND CONCLUSION}

For the treatment of AA, we selected CARN (an effective natural endogenous antioxidant), its novel derivative (S)-6hydroxy-2,5,7,8-tetramethylchroman-2-carbonyl- $\beta$-alanyl-Lhistidine, which was synthesised by condensing the $\beta$-amino group of L-carnosine and the carboxyl group of a lipophilic antioxidant (S)-TroloxTM, and the standard antioxidant TRO [2]. Arthritis induced in rats with intradermal injection of adjuvants containing mycobacteria is an animal model often used for the evaluation of potential anti-rheumatic drugs [5]. AA is a chronic model in comparison to carrageenan-induced oedema, which represents a typical acute inflammatory model [6]. For monitoring AA progression, the changes in the body weight and hind paw volume increase are frequently used. On day 28 , all substances administered were effective in decreasing the hind paw volume. Interestingly, even though TRO decreased the hind paw volume, it had a cachectic effect on arthritic rats and intensified the weight loss when compared to AA. There is an experimental evidence that the pro-inflammatory cytokine $\mathrm{IL}-1$ is implicated in the pathogenesis of RA in a significant way [7]. All substances administered decreased the IL-1 $\beta$ to a basal level. The synovial fluid (SF) and serum MCP-1 concentrations are significantly higher in RA patients [8]. On day 14, CARN-T and TRO, but not CARN, significantly decreased the levels of MCP-1. It seems that addition of the TRO molecule to CARN increases its ability to reduce MCP-1 during AA development. MMP-9 plays several important functions within neutrophil action, such as degrading extracellular matrix, activation of IL-1 $\beta$, 
Table 1. Clinical parameters during AA: time profiles of hind paw volume increase and change in body weight.

Data are expressed as mean $\pm S E M .{ }^{* * *} p<0.001$ vs. CO - healthy control, $+p<0.05$ vs. $A A$ - adjuvant arthritis, $++p<0.01$ vs. $A A,+++p$ $<0.001$ vs. $A A$

\begin{tabular}{|c|c|c|c|c|c|}
\hline Clinical parameters & CO & AA & CARN & CARN-T & TRO \\
\hline $\begin{array}{l}\text { Change in body weight, } \\
\text { day } 14\end{array}$ & $79.1 \pm 3.8$ & $\underset{* * *}{40.1 \pm 2.6}$ & $46.5 \pm 3.8$ & $39.5 \pm 2.4$ & $33.2 \pm 5.0$ \\
\hline $\begin{array}{l}\text { Change in body weight, } \\
\text { day } 21\end{array}$ & $96.7 \pm 7.2$ & $\underset{* * *}{28.6 \pm 2.5}$ & $34.9 \pm 2.9$ & $24.5 \pm 1.9$ & $21.0 \pm 2.8$ \\
\hline $\begin{array}{l}\text { Change in body weight, } \\
\text { day } 28\end{array}$ & $118.2 \pm 7.3$ & $\underset{* * *}{55.3 \pm 3.1}$ & $59.8 \pm 4.4$ & $47.1 \pm 3.7$ & $\begin{array}{c}28.6 \pm 3.6 \\
++\end{array}$ \\
\hline $\begin{array}{l}\text { Increase in the hind } \\
\text { paw volume, day } 14\end{array}$ & $12.4 \pm 0.8$ & $\underset{* * *}{52.6 \pm 5.5}$ & $37.7 \pm 6.6$ & $\begin{array}{c}30.9 \pm 4.5 \\
+\end{array}$ & $\begin{array}{c}26.0 \pm 6.7 \\
++\end{array}$ \\
\hline $\begin{array}{l}\text { Increase in the hind } \\
\text { paw volume, day } 21\end{array}$ & $17.2 \pm 2.0$ & $\underset{* * *}{71.2 \pm 5.3}$ & $62.0 \pm 3.4$ & $59.5 \pm 4.0$ & $\begin{array}{c}53.1 \pm 5.4 \\
+\end{array}$ \\
\hline $\begin{array}{l}\text { Increase in the hind } \\
\text { paw volume, day } 28\end{array}$ & $17.8 \pm 2.1$ & $\underset{* * *}{78.6 \pm 8.2}$ & $\begin{array}{c}52.4 \pm 3.1 \\
++\end{array}$ & $\begin{array}{l}49.2 \pm 3.9 \\
+++\end{array}$ & $\begin{array}{l}41.2 \pm 3.0 \\
+++\end{array}$ \\
\hline
\end{tabular}

Table 2. Inflammatory markers - IL-1 $\beta, M C P-1$, and MMP-9 measured in plasma on day 14.

Data are expressed as mean \pm SEM. ${ }^{* * *} p<0.001$ vs. CO - healthy control, $+p<0.05$ vs. AA - adjuvant arthritis, $++p<0.01$ vs. $A A,+++p$ $<0.001$ vs. $A A$

\begin{tabular}{|c|c|c|c|c|c|}
\hline $\begin{array}{c}\text { Inflammatory } \\
\text { parameters }\end{array}$ & CO & AA & CARN & CARN-T & TRO \\
\hline $\mathrm{IL}-1 \beta(\mathrm{pg} / \mathrm{ml})$ & $7.46 \pm 0.75$ & $\begin{array}{c}94.49 \pm 26.32 \\
* * *\end{array}$ & $\begin{array}{c}17.24 \pm 3.05 \\
+++\end{array}$ & $\begin{array}{c}17.53 \pm 4.70 \\
+++\end{array}$ & $\begin{array}{c}13.89 \pm 3.89 \\
+++ \\
+++\end{array}$ \\
\hline $\mathrm{MCP}-1(\mathrm{pg} / \mathrm{ml})$ & $9077 \pm 726$ & $\begin{array}{c}20806 \pm 1670 \\
* * *\end{array}$ & $17213 \pm 1393$ & $\begin{array}{c}15803 \pm 1335 \\
+\end{array}$ & $\begin{array}{c}14204 \pm 617 \\
++\end{array}$ \\
\hline $\mathrm{MMP}-9(\mathrm{ng} / \mathrm{ml})$ & $37.88 \pm 3.55$ & $\begin{array}{c}133.57 \pm 9.31 \\
* * *\end{array}$ & $\begin{array}{c}60.59 \pm 6.18 \\
+++\end{array}$ & $\begin{array}{c}75.14 \pm 11.24 \\
+++\end{array}$ & $\begin{array}{c}61.73 \pm 4.44 \\
+++\end{array}$ \\
\hline
\end{tabular}

and cleavage of several chemokines. MMP-9 was found to be elevated in patients sera and SF and may be referred to as good laboratory marker for RA [9]. Our experimental substances were all effective in reducing this marker. In conclusion, all compounds studied corrected the clinical parameter - hind paw volume. The most effective was TRO. However, TRO had an adverse effect on the body weight of arthritic animals. All compounds assessed influenced in a beneficial way all parameters tested in plasma. In the case of IL-1 $\beta$ and MMP9 , levels close to the control values were achieved. On the basis of the obtained results, we would choose CARN-T as the most suitable compound for further studies, focussed on the combination therapy with low dose of methotrexathe in AA.

\section{ACKNOWLEDGEMENT}

This work was supported by grant VEGA 2/0044/15 and bilateral SAS-RAMS project 2013-2015, coordinated by Dr. Bauerova (Slovakia) and Dr. Fedorova (Russia).

\section{References}

[1] Boldyrev AA, Severin SE. The histidine-containing dipeptides, carnosine, and anserine: distribution, properties, and biological significance. Adv. Enz. Reg. 1990; 30: 175-193.

[2] Stvolinsky S, Toropova K, Gordeeva M, Kazey V, Sato T, Meguro $\mathrm{K}$, Boldyrev A. Carnosine and its (S)-Trolox ${ }^{\mathrm{TM}}$ derivative protect animals against oxidative stress. Amino. Acids. 2012; 43: 165-70.
[3] Stvolinsky SL, Bulygina ER, Fedorova TN, Meguro K, Sato T, Tyulina OV, Abe H, Boldyrev AA. Biological activity of novel synthetic derivatives of carnosine. Cell. Mol. Neurobiol. 2010; 30: 395-404.

[4] Bauerova K, Ponist S, Kuncirova V, Mihalova D, Paulovicova E, Volpi N. Chondroitin sulfate effect on induced arthritis in rats. Osteoarthr. Cartil. 2011; 19: 1373- 1379. 
Eur. Pharm. J. LXIII, 2016 (1): 16-19.

Evaluation of the effect of carnosine, its novel derivative trolox-carnosine and trolox in ...

[5] Joe B, Griffiths MM, Remmers EF, Wilder RL. Animal models of rheumatoid arthritis and related inflammation. Curr. Rheumatol. Rep. 1999; 1: 139-148.

[6] Sokolík, Tumova, Valentová, Švec. Anti-inflammatory activities of copper(II) and zinc(II) Y-methoxyphenoxyacetates ( $\mathrm{Y}=2,3$ or 4) on carrageenan-induced edema. Acta Facultatis Pharmaceuticae Universitatis Comenianae. 2007; 54: 165-170.

[7] Kay J, Calabrese L. The role of interleukin-1 in the pathogenesis of rheumatoid arthritis. Rheumatology. (Oxford) 2004; 43: iii2-iii9.
[8] Stankovic A, Slavic V, Stamenkovic B, Kamenov B, Bojanovic M, Mitrovic DR. Serum and synovial fluid concentrations of CCL2 (MCP-1) chemokine in patients suffering rheumatoid arthritis and osteoarthritis reflect disease activity. Bratisl. Lek. Listy. 2009; 110: 641-646.

[9] Gruber BL, Sorbi D, French D, L. Marchese MJ, Nuovo GJ, Kew RR, Arbeit LA. Markedly elevated serum MMP-9 (gelatinase B) levels in rheumatoid arthritis: a potentially useful laboratory marker. Clin. Immunol. Immunopathol. 1996; 78: 161-71. 